\title{
The Influence of Statistical Anxiety on Statistic Reasoning of Pre- service Mathematics Teachers
}

\section{La influencia de la ansiedad estadística en el razonamiento estadístico de los docentes de matemática con formación inicial}

\author{
Yusfita Yusuf* \\ ORCID iD 0000-0001-5899-3381 \\ Hardi Suyitno** \\ ORCID iD 0000-0002-4894-7020 \\ Y. L. Sukestiyarno*** \\ ORCID iD 0000-0002-2787-0888 \\ Isnarto $^{* * * *}$ \\ ORCID iD 0000-0002-6134-4195
}

\begin{abstract}
The large number of statistical data present in everyday life makes statistical reasoning an absolute ability possessed by students. Meanwhile, the statistical reasoning is influenced by various cognitive and non-cognitive factors. This study emphasizes the influence of non-cognitive factors, which are the statistical anxiety. The purpose of this study is to describe the statistical anxiety of pre-service mathematics teacher and the influence of statistical anxiety on statistical reasoning. This research method is a mixed-method with sample of 33 pre-service teachers who are taking basic statistics courses. The instrument used in this study is a statistical anxiety questionnaire developed by Earp (2007) and a statistical reasoning test developed by Chan et al (2016). The result showed that the statistical anxiety of pre-service mathematics teachers was in the moderate level on the aspects of taking the courses, studying and practicing; and was in the higher level on the aspect of the examination. Statistical anxiety levels on every aspect are equally good for both men and women. Statistical anxiety does not directly affect the ability of statistical reasoning and it can only impair $0.1 \%$ of the statistical reasoning ability. On reasoning indicators and statistical anxiety indicators, there are relevant results between the

\footnotetext{
* Mestre em Educação Matemática pela Universitas Pendidikan Indonesia (UPI), Bandung.Docente de Educação Matemática na Sekolah Tinggi Keguruan dan Ilmu Pendidikan (STKIP) Sebelas April, Sumedang. Endereço para correspondência: Jl. Angkrek Situ No.19, Sumedang Utara, Sumedang Regency, Java Ocidental, Indonésia, Código postal: 45323. E-mail: yusfitayusuf87@gmail.com.

** Doutor em Filosofia em Matemática pela Universitas Negri Yogyakarta (UNY), Yogyakarta. Professor de Educação Matemática da Universitas Negri Semarang (Unnes), Semarang. Endereço para correspondência: Departamento de Matemática FMIPA Unnes, Campus Sekaran, Gunungpati, Semarang, Java Central, Indonésia, Código postal: 50233. E-mail: hardi.suyitno@mail.unnes.ac.id.

*** Doutor em Estatística Econômica pela Dortmund Universitat, Dortmund. Professor de Matemática (estatísticas) da Universitas Negri Semarang (Unnes), Semarang. Endereço para correspondência: Departamento de Matemática FMIPA Unnes, Campus Sekaran, Gunungpati, Semarang, Java Central, Indonésia, Código postal: 50233. E-mail: sukestiyarno@gmail.com.

***** Doutor em Educação Matemática pela Universitas Pendidikan Indonesia (UPI), Bandung. Docente de Educação Matemática da Universitas Negri Semarang (Unnes), Semarang. Endereço para correspondência: Departamento de Matemática FMIPA Unnes, Campus Sekaran, Gunungpati, Semarang, Java Central, Indonésia, Código postal: 50233. E-mail: isnarto.math@mail.unnes.ac.id.
} 
statistical anxiety experienced by the pre-service teachers on the indicator for developing conclusions based on mathematical solutions, explaining statistical findings, and interpreting statistics with indicators on statistical reasoning; they areanalyzing and interpreting data.

Keywords: Statistical anxiety. Statistical reasoning. Cognitive factor. Non-cognitive factor

\section{Resumen}

La gran cantidad de datos estadísticos que se presentan en la vida cotidiana hace que el razonamiento estadístico sea una habilidad absoluta que poseen los estudiantes. Mientras tanto, el razonamiento estadístico está influenciado por diversos factores, tanto cognitivos como no-cognitivos. Este estudio enfatiza la influencia de los factores no-cognitivos, que es la ansiedad estadística. El propósito de este estudio es describir la ansiedad estadística del profesor de matemáticas (que tenga una formación inicial que le permita ingresar en la profesión docente) bajo la influencia de la ansiedad estadística en el razonamiento estadístico. En esta investigación se utiliza el método mixto, con una muestra de 33 maestros con formación inicial, participantes de una conferencia de estadística básica. El instrumento utilizado en este estudio es un cuestionario de ansiedad estadística desarrollado por Earp (2007), y una prueba de razonamiento estadística desarrollada por Chan et al (2016) El resultado mostró que la ansiedad estadística de estos profesores de matemáticas estaba en el nivel moderado sobre los aspectos de participar de los cursos, estudiar y practicar, y estaba en el nivel superior en el aspecto del examen. Los niveles de ansiedad estadística, en todos los aspectos,permanecen iguales tanto para hombres como para mujeres. La ansiedad estadística no afecta directamente la capacidad del razonamiento estadístico, la ansiedad estadística puede predecir en un $0,1 \%$ de la capacidad del razonamiento estadístico. En los indicadores de razonamiento y los indicadores de ansiedad estadística, hay resultados relevantes entre la ansiedad estadística experimentada por los docentes estudiados, sobre el indicador relativo a desarrollar conclusiones basadas en soluciones matemáticas, explicar hallazgos estadísticos e interpretar estadísticas con indicadores de razonamiento estadístico; están analizando e interpretando dados.

Palabras clave: Ansiedad estadística. Razonamiento estadístico. Factor cognitivo. Factor no-cognitivo.

\section{Background}

Statistics can be viewed as a tool to solve problems that always occur in everyday life, at work, and in science (MOORE, 1997). NCTM (2005) and Watson; Callingham (2003) stated that currently there are many statistical data in daily life such as the number of participants in debates or community actions, phenomena such as crime rate, population growth, disease spread, production numbers, educational attainment, job trends, etc. To understand the statistical data, it is required the statistical reasoning ability (KARATOPRAK;AKAR; BÖRKAN, 2015; AGUS; PENNA; CEBOLLERO; OLMOS; PESSA, 2014). Statistical reasoning is defined as a way of reasoning with statistical ideas and understanding statistical information (GAL; GARFIELD, 1997). Lovett (2001) interprets statistical reasoning as in using statistical tools and concepts to make summaries, predictions, and draw conclusions from data. This is in line with Ben-Zvi; Garfield (2004) who stated that statistical reasoning is a way of thinking by using statistical information. While Del Mas (2002) argued that statistical reasoning is the ability to explain why and how to generate the results and why and how to draw conclusions. 
Rumsey(2002) stated that the goal of statistical learning is that students understand statistics well in order to get information from the existing data, criticize and make decisions based on that information and aim to develop research skills. Garfield; Ben-Zvi (2005) stated that the statistics course has also become a requirement for completing courses in various fields of study.

However, some studies show that students from elementary to university levels face difficulties in learning statistics (CHAN; ISMAIL; SUMINTONO, 2015). The difficulty occurs because the students do not know the concepts, the interrelationships between concepts and how to apply the concept in real problems (JIN; KIM; MCGHAKEE; REISER, 2011; CHIESI; PRIMI, 2010). As a result, it is assumed that statistics courses are difficult subjects that can prevent them from completing their studies (GAL; GINSBURG IN JIN; KIM; MCGHAKEE; REISER, 2011). Perceptions of statistics as a difficult course also occur at the place where researchers are working. Moreover, in the last few years there has been a shift in learning objectives that emphasized on procedural understanding to emphasize more on understanding the concept and developing thestatistical reasoning (JIN; KIM;MCGHEE; REISER, 2011; TÜREGÜN, 2014; IDRIS; YANG, 2015; CHAN; ISMAIL; SUMINTONO, 2015; KALOBO, 2016). The shift in the purpose of statistical learning is done to overcome the problems that occur in statistical learning.

Rosidah (2016) said teachers need to use the stage of statistical reasoning so that students can be trained in statistical reasoning as early as possible. Statistical reasoning is an important cognitive skill to master and it is related to students' content knowledge. Several studies have shown that teaching of statistical reasoning can affect student achievement (ZURAIDA et al., 2012; TEMPELAR; VAN DER LOEFF; GIJLSELAERS, 2007). The preservice mathematics teachers must possess qualified statistical reasoning abilities (GARFIELD, 2002), so they can pass on their knowledge to their students (KARATOPRAK;AKAR; BÖRKAN, 2015).

Studies have shown that the results of statistical learning are directly influenced by various cognitive and non-cognitive factors (TREMBLAY; GARDNER; HEIPEL, 2000; NASSER, 2004; CHIESI; PRIMI, 2010; LAI; TANNER; STEVENS, 2011; KHENG; IDRIS; MOHAMED; LYN, 2016; KHENG; AZLAN; AHMAD; LEONG; MOHAMED, 2016). The cognitive factor is the background of mathematical ability, while the non-cognitive factors are attitudes toward statistics and anxiety (CHIESI; PRIMI, 2015). Some studies suggest that anxiety is a major factor predicting statistical achievement (FITZGERALD; JURS; HUDSON IN CHIESI; PRIMI; CARMONA, 2011; LAI; TANER; STEVENS, 2011), while 
others suggest that anxiety has indirect effects, as anxiety may be attenuated or mediated by other individual characteristics, such as mathematical ability, self-efficacy, or attitude (CHIESI; PRIMI, 2010; ONWUEGBUZIE; WILSON, 2003; TREMBLAY; GARDNER; HEIPEL, 2000).

Statistical anxiety is defined as the anxiety that arises when taking a statistical course or while working on statistical analysis that includes data collection, processing, and interpretation (CRUISE; CASH; BOLTON, 1985). Statistical anxiety is a state in which a person experiences strong fears, dislikes, mental disorders, tensions, and mental emotions when dealing with concepts, problems, learning, and statistical evaluation (ZIDNER, 1991). Onwuegbuzie and Wilson (2003) defined statistical anxiety as the fear that occurs when a student takes statistics in any form and at any level. Statistical anxiety occurs when one is studying statistical concepts and requirements and also its application in a specific context (LAVASANI; WEISANI; SHARIATI, 2013). Thus, statistical anxiety is a feeling of worry, tension and fear when students learn, take, and apply statistics.

Several studies have examined the impact of statistical anxiety. Statistical anxiety besides providing impact on statistical learning outcomes also has an impact on overall learning outcomes (WILLIAMS, 2010). Onwuegbuzie; DaRos; Ryan (1997) states that that statistical anxiety is related to mathematical anxiety. Statistical anxiety felt by a math prospective teacher will have an impact on learning self-confidence. Like the prospective teacher who experience math anxiety andmay affect his or her teaching confidence(BRADY; BOWD, 2005)

This study will examine whether pre-service mathematics teacher have statistical anxiety and how the statistical anxiety influences the ability of statistical reasoning. The subjects are pre-service mathematics teachers in one of the universities in West Java. This research is important because pre-service mathematics teacher private universities did not go through the screening process as strict as the students who go to a State University. On this research, we will obtain the statistical anxiety descriptions and its influence on the statistical reasoning on pre-service mathematics teachers.

\section{Research Method}

The method used in this research is a mixed-method research. The study was conducted in one class of 33 people of 3rd semester students who attended the basic statistics course. There were 10 men and 23 women. The sample selection was done considering the 
material taught in basic statistics courses and emphasized more on the matters which may be used by the students as the provision for teaching either at junior high school or senior high school.

The data collection technique done in this research consisted of two stages: acquiring quantitative data with the statistical reasoning test and statistical anxiety questionnaire, after that, the observation and interview were done to explore the result in the quantitative stage. The instrument used to collect data is a matter of statistical reasoning test adopted from the instrument developed by Chan et al.(CHAN; ISMAIL; SUMINTONO, 2016) The adoption process carried out on reasoning instruments is to adjust the material to be examined with statistical reasoning indicators that have been developed by Chan et al. (CHAN; ISMAIL; SUMINTONO, 2016) (The questionnaire instrument of statistical anxiety was adopted from an instrument developed by Earp. The anxiety factors found in Earp's study were sorted into three conditions, namely when taking courses, while studying (learning and training) and when examining.

The results of statistical reasoning and anxiety tests were analyzed using statistical regression tests to determine the relationship between statistical anxiety and statistical reasoning. These results were explored with the help of interviews and observations. Interviews were only conducted on 6 students with criteria determined by the researchers based on the results of statistical reasoning tests and statistical anxiety questionnaire. Observations were done during basic statistical learning and during statistical reasoning tests.

\section{Results}

The statistical anxiety analysis result, which wasapplied to 33 students, is presented in the following table.

Table1-The Score and Classification of Statistical Anxiety on Pre-service Mathematics Teacher

\begin{tabular}{|c|c|c|c|c|c|c|c|c|c|c|c|c|}
\hline & \multicolumn{11}{|c|}{ Statistical Anxiety } & \\
\hline & \multicolumn{3}{|c|}{ Taking the course } & \multicolumn{3}{|c|}{$\begin{array}{l}\text { Learn and } \\
\text { practice }\end{array}$} & \multicolumn{3}{|c|}{ Exams } & \multicolumn{3}{|c|}{ Total } \\
\hline \multirow{3}{*}{ Gender } & & & leve & & & $\overline{\text { leve }}$ & & & & & & leve \\
\hline & $\bar{x}$ & $\%$ & 1 & $\bar{x}$ & $\%$ & 1 & $\bar{x}$ & $\%$ & level & $\bar{x}$ & $\%$ & 1 \\
\hline & & & & & 52 & & & 77 , & & & 51,2 & \\
\hline \multirow[t]{2}{*}{ Men } & 2,7 & 33,75 & M & 14,7 & 5 & $\mathrm{M}$ & 3,1 & 5 & $\mathrm{H}$ & 20,5 & 5 & $\mathrm{M}$ \\
\hline & & & & & 50 & & & 72 , & & 21,3 & 53,2 & \\
\hline Women & 3,5 & 44,02 & M & 10,7 & 3 & M & 2,9 & 8 & $\mathrm{H}$ & 0 & 6 & $\mathrm{M}$ \\
\hline
\end{tabular}


Source: research data.

Table 1 showed that overall statistical anxiety of pre-service mathematics teacher is at a moderate level in both men and women. If we look carefully at table 1, it shows that the anxiety characteristics in both men and women are similar. This is consistent with research conducted by Baloğlu (2003), Cruise and Wilkins (in BALOĞLU; DENIZ; KESICI, 2011)and Eduljee dan LeBourdais (2015) where they cannot find a significant difference between men and women with statistical anxiety.

Looking at each activity, students' statistical anxiety on taking courses and learning and practicing are at moderate level. It is also reinforced by interviews and observations during learning, where students feel comfortable during statistical learning. They can understand and do the exercises with the guidance of courses. When taking a course, students do not feel anxious because they are ready with their chosen course of study. It's just that they feel very anxious when the date of the exam is announced. Sometimes, before the exam, the tension will be very visible in between the students, with them usually asking about the learning materials, especially on result interpretation. Therefore, anxiety at an exam activity is at a high level. The reason for their anxiety is because they are afraid of not being able to answer the questions and get a low score. If you look at the observation results, here is where students feel tense when they are about to face exams and have to prepare better for the exam, this means statistical anxiety becomes the motivation for students to learn. This is consistent with Thorndike's view of stimulus-response, i.e. the consequence of a particular behavior will play a very important role in subsequent behavior (SLAVIN, 2006). In this case, anxiety is manifested as a reaction to learning cues that statistics as a subject is one of the hardest courses and only smart people can do well. Students with higher level intelligence criteria are even more prepared for the exam.

When viewed on the average of each activity there is a mean difference. In the activity of taking courses, women have higher levels of anxiety than men. Based on interviews, women feel worried because they feel that their mathematical abilities are lacking and have low self-efficacy. While men assume that they have high confidence that they can master statistics due to having reasoning skills. This is in line with Mills's opinion (in EDULJEE; LEBOURDAIS, 2015), namely men feel more confident in mastering statistics, are not afraid of statistics and can learn statistics.On the other hand,in learning activities and training as well as in the exam activities men have a higher level of statistical anxiety than women. The results of this study are not in line with the results of the research by Eduljee and LeBourdais (2015) which state that the statistical anxiety level in women is higher than in men during 
examinations and learning. But they are in line with the results of Mandap's study (2016) where men have high levels of statistical anxiety compared to women. Researchers suspect that socio-cultural factors are one of the factors that influence statistical anxiety, since the research conducted by Eduljee and Lebourdais was conducted in the United States and the research conducted by Mandap was in the Philippines. In learning and training activities, women work harder than men. Women record every explanation and completion step in each given exercise. When experiencing difficulties, women do not hesitate to ask the teacher. This is different from men who feel confident of being able to master statistics so that they pay less attention and are reluctant to ask question when experiencing difficulties. This is in accordance with traditional masculine norms because men feel strong and free, so they are reluctant to ask for academic assistance (WINER IN MANDAP, 2016).The impact is a lack of learning and training, so that men feel high statistical anxiety during the exam.

In this study, we will analyze the relationship between statistical anxiety with statistical reasoning. The analysis was performed using simple linear regression with the help of SPSS.

The results of the analysis are presented in Figure 1.

\begin{tabular}{l} 
Model Summary \\
\begin{tabular}{|l|l|r|r|r|}
\hline Mode & $\mathrm{R}$ & R Square & $\begin{array}{c}\text { Adjusted R } \\
\text { Square }\end{array}$ & $\begin{array}{c}\text { Std. Error of } \\
\text { the Estimate }\end{array}$ \\
\hline 1 & $.026^{\beth}$ & .001 & -.032 & 21.88603 \\
\hline
\end{tabular} \\
\hline
\end{tabular}

ANOVA ${ }^{\text {b }}$

\begin{tabular}{|rl|r|r|r|r|r|}
\hline \multicolumn{1}{|c|}{} & \multicolumn{1}{c|}{$\begin{array}{c}\text { Sum of } \\
\text { Squares }\end{array}$} & df & Mean Square & \multicolumn{1}{c|}{ F } & Sig. \\
\hline 1 & Regression & 9.959 & 1 & 9.959 & .021 & $.886^{=}$ \\
& Residual & 14848.951 & 31 & 478.998 & & \\
& Total & 14858.909 & 32 & & & \\
\hline
\end{tabular}

a. Predictors: (Constant), SA

b. Dependent Variable: SR

\begin{tabular}{|c|c|c|c|c|c|c|}
\hline \multicolumn{7}{|c|}{ Coefficients ${ }^{3}$} \\
\hline \multirow{2}{*}{\multicolumn{2}{|c|}{ Madel }} & \multicolumn{2}{|c|}{ Unstandardized Coefficients } & $\begin{array}{c}\text { Standardized } \\
\text { Coefficients }\end{array}$ & \multirow[b]{2}{*}{$t$} & \multirow[b]{2}{*}{ Sig. } \\
\hline & & $\mathrm{B}$ & Std. Error & Beta & & \\
\hline 1 & (Constant) & 42.363 & 13.175 & & 3.215 & .003 \\
\hline & $\mathrm{SA}$ & .087 & .601 & .026 & .144 & .886 \\
\hline
\end{tabular}

Picture1.The Output of the data analysis with SPSS Source: research data.

The sig value in the table coefficients is equal to 0,886 , mean sig. greater than 0.05 , so it can be concluded that statistical anxiety does not directly affect the ability of statistical reasoning. The value of $\mathrm{R}$ square in the summary model table shows the value of 0.001 . This means that statistical anxiety only affects $0.1 \%$ of the ability of statistical reasoning while the 
rest is influenced by other factors both cognitive factors and non-cognitive factors. The results of this study are consistent with the results of Chiesi; Primi's research (2010), Onwuegbuzie; Wilson (2003), and Tremblay; Gardner; Heipel (2000) which suggested that anxiety effects may be attenuated or mediated by other individual characteristics, such as mathematical ability, self-efficacy, or attitude.

Interviews showed that students did not feel tense when learning, but some admitted that they were confused by the reasoning tests given. Given problems of statistical reasoning have indicators: 1) describing data; 2) organizing and reducing data; 3) representing data; 4) analyzing and interpreting data. One of the questions of statistical reasoning given can be seen below.

Observe the table and graph below!

\begin{tabular}{|l|l|l|}
\hline No & Interval & Frequency \\
\hline 1 & $20-30$ & 5 \\
\hline 2 & $31-41$ & 7 \\
\hline 3 & $42-52$ & 12 \\
\hline 4 & $53-63$ & 9 \\
\hline 5 & $64-74$ & 5 \\
\hline 6 & $75-85$ & 2 \\
\hline
\end{tabular}

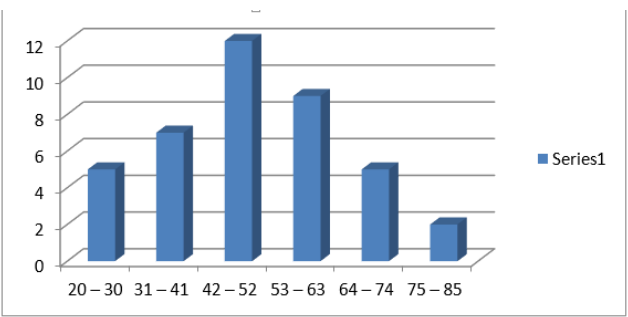

a. Do tables and graphs represent the same data? Please, explain!

b. Among the two data presentations above, which one is more easily understood? Please, explain!

c. From the graph above, looking at its slope, what kind of curves does it have? Please, explain!

d. Please specify the range of the table above! Please, explain!

$e$. Determine the data number and length of classes.

Problems a) and b) are questions with indicators representing data, problem c) is a question with an indicator analyzing and interpreting data, question d) is a question with an indicator organizing and reducing data, and problem e) is a question with an indicator describing data. In general, students admitted difficulty when working on this problem; they cannot explain exactly what is being asked. They focused more on calculations, procedures and graphics, so when they were given this kind of problem as above, they faced difficulty. For questions on problem e), they preferred to work by counting them and not by interpreting the data presented in the table. This is consistent with some evidence to suggest that pre-service mathematics teacher have higher competencies on how to read graphs (GONZÁLES; ESPINEL; AINLEY, 2011) and calculate sizes(JACOBBE; CARVALHO, 2011; SÁNCHEZ; SILVA; CAUTNHO, 2011). 
The difficulties they encounter in performing statistical reasoning tests are on indicators of analyzing and interpreting data. In statistical anxiety, there are also indicators in accordance with statistical reasoning indicators, which is to develop conclusions based on mathematical solutions, explain statistical findings, and interpret statistics. On the indicator, students experienced greater anxiety compared to other anxiety indicators such as reading, calculating, and solving mathematical equations. Observations during the study and interviews indicate that it is because students focused too much on numbers and calculations, and when they finish calculating they assume the problem is over. They cannot explain the obtained calculation results and how to interpret them. Students argued that they did it a lot during high school and the lack of reinforcement from the teacher about this process causeddifficulty as well. This is consistent with Leavy; Hannigan; Fitzmaurice's (2013) research, where teachers assume that students have difficulty interpreting graphs and statistical results. This is most likely because most teachers skipped this stage in class. Although, in the basic statistics courseit has been emphasized that this stage needs to be carried out.

\section{Conclusions and Suggestions}

From this research results and discussion, we can conclude that pre-service mathematics teachers still have statistical anxiety with moderate level on aspects of taking courses, learning and practicing while the aspect of the examination has a higher anxiety level. Statistic anxiety on the aspect of the exam leads them to prepare themselves better, so statistical anxiety here becomes a boost or motivation for them to learn. Based on gender, both men and women have the same anxiety level on various aspects. The results of statistics tests show that statistical anxiety has no effect on the statistical reasoning ability, statistical anxiety can only impair $0.1 \%$ the ability of statistical reasoning. This means that many other factors affect statistics reasoning, both cognitive factors and non-cognitive factors. Weanalyzed the indicator of statistical reasoning and statistical anxiety indicators, in which there is relevant results between statistical anxiety experienced by students on the indicator to develop conclusion based on mathematical solution, explain statistical findings, and to interpret statistic; with the indicator of statistical reasoning, which is analyzing and interpreting data. Therefore, these pre-service mathematics teachers need to be given sufficient mastery of pedagogical material, content and knowledge of statistics, as well as strengthen the indicators of analyzing and interpreting data. This should be done in order to 
reduce their statistical anxiety andso they can become professional teachers. Looking at the results of this study, it is necessary to conduct further research to examine the factors that affect students' reasoning abilities of statistics for both cognitive and non-cognitive factors.

\section{References}

AGUS, M. et al. The Aplication of Graphical Representations. In: Estimatian Of Probabilistic Events. Journal Of Theories and Research in Education, Bologna, v. 9, n. 1, p. 235-252, 2014.

BALOĞLU, M. Individual differences in statistics anxiety among college students. Personality and Individual Differences, Ontario, v. 34, p. 855-865, 2003

BALOĞLU, M.; DENIZ, E.; KESICI, Ş. A descriptive study of individual and cross-cultural differences in statistics anxiety. Learning and Individual Differences, Texas, v. 21, p. 387-391, March 2011

BEN-ZVI, D.; GAFIELD, J. The Challenge of Developing Statistical Literacy, Reasoning, and Thinking. Dordrecht: MA Kluwer Academic Publisher, 2004. p. 121-146.

BRADY, P.; BOWD, A. Mathematics anxiety, prior experience, and confidence to teach mathematics among pre-service education students. Teachers and Teaching: Theory and Practice, Philadelphia, v.1 1, n. 1, p. 37-46, 2005.

CHAN,S. W.; ISMAIL, Z.; SUMINTONO, B. Assessing Statistical Reasoning In Descriptive Statistics: A Qualitative Meta-Analysis. Journal Teknologi (Sciences \& Engineering), Kuala Lumpur, v. 78, n. 6-5, p. 29-35, jan. 2015.

CHAN,S. W.; ISMAIL, Z.; SUMINTONO, B. A Framework for Assessing High School Students' Statistical Reasoning.PLOS ONE, Kuala Lumpur, v. 11, n. 11, p. 1-32, nov. 2016.

CHIESI, F.; PRIMI, C. Cognitive and non-cognitive factors related to students' achievement. Statistics Education Research Journal, Auckland, v. 9, n. 1, p. 6-26, 2010.

CHIESI, F.; PRIMI, C.; CARMONA, J. Measuring Statistics Anxiety: Cross-Country Validity of the Statistical Anxiety Scale (SAS).Journal of Psychoeducational Assessment, Ontario, v. 29, n. 6, p. 559-569, 2011.

CHIESI, F.; PRIMI, C. Gender differences in attitudes toward statistics: Is there a case for a confidence gap? IN: CERME 9 - NINTH CONGRESS OF THE EUROPEAN SOCIETY FOR RESEARCH IN MATHEMATICS EDUCATION, 9., 2015.Prague.Proceedings of ERME Prague: HAL, 2015. p. 622-628.

CRUISE, R. J.; CASH, R. W.; BOLTON, D. L. Development and validation of an instrument to measure statistical anxiety. In: ANNUAL MEETINGOF THE AMERICAN STATISTICAL ASSOCIATION STATISTICS EDUCATION SECTION, 1985.Chicago. Proceding of the American Statistical Association Dublin: OCLC, 1985. p. 417-425.

DELMAS, R. Statistical Literacy, Reasoning, and Learning: A Commentary. Journal of Statistics Education, New York, v. 10, n. 3, p. 1-11,2002.

EARP, M. S.Development and Validation of the Statistics Anxiety Measure. 2007.P. 151154f.Tesis (Doctorate of Philosophy)-College of Education, University of Denver, 2007. 
EDULJEE, N. B.; LEBOURDAIS, P. Gender Differences in Statistics Anxiety with Undergraduate College Students. The International Journal of Indian Psychology, Gujarat, v. 2, n. 3, p. 69-82, 2015.

GAL, I.; GARFIELD,J. B. Teaching and Assesing Statistical Reasoning. NCTM, 1997.

GARFIELD, J. B.The Chalange of Develoving Statistical Reasoning. Journal of Statistics Education, New York, v. 10, n. 3,p. 1-12, 2002.

GARFIELD, J.; BEN-ZVI, D. How students learn statistics revisited: A current review of research on teaching and learning statistics. International Statistical Review,Voorburg, v. 75, n. 3,p. 371-396, 2005.

GONZÁLES, M. T.; ESPINEL, M. C.; AINLEY, J. “Teachers' Graphical Competence,”. In: BATANERO, C.; BURRILL, G.; READING, C.(Ed.).Teaching Statistics in School MathematicsChallenges for Teaching and Teacher Education: A Joint ICMI/IASE Study. New York: Springer, 2011. p. 187-197.

IDRIS, K.; YANG, K. Analysis of tasks in statistics textbooks for future English teachers based on statistical cognitions. In: ICMI-EAST ASIA REGIONAL CONFERENCE ON MATHEMATICS EDUCATION, 7., 2015, Cebu City. Proceding of ICMI, Cebu City: Philippine Council of Mathematics Teacher Educators, 2015. p. 321-327.

JACOBBE, T.; CARVALHO, C.. "Teachers' Understanding of Averages,". In: BATANERO, C.; BURRILL, G.; READING, C. (Ed.).Teaching Statistics in School Mathematics-Challenges for Teaching and Teacher Education: A Joint ICMI/IASE Study. New York: Springer, 2011. p. 199209.

JIN, L. et al. Statistical Reasoning Skills and Attitude: The Effect of Worked Examples. In: AECT INTERNATIONAL CONVENTION, 2011. JACKSONVILLE. Proceedings of 2011 AECT International Convention, Jacksonville: FI, 2011. p. 105-110.

KALOBO, L. Teachers' Perceptions of Learners' Proficiency in Statistical Literacy, Reasoning and Thinking. African Journal of Research in Mathematics, Science and Technology Education, Eastern Cape, v. 20,n. 3, p. 225-233, 2016.

KARATOPRAK, R.; AKAR, G. K.; BENGÜ BÖRKAN, B. Prospective Elementary And Secondary School Mathematics Teachers' Statistical Reasoning. International Electronic Journal of Elementary Education, Oslo, v. 7, n. 2, p. 107-124, 2015.

KHENG, F. K. et al. A multiple regression model of statistical reasoning: A Malaysian context. OIDA International Journal of Sustainable Development, Ontario, v. 09, n. 10, p. 59-70, 2016.

KHENG, F. K.et al. Relationship between Cognitive Factors and Performance in an Introductory Statistics Course: a Malaysian Case Study. Malaysian Journal of Mathematical Sciences, Selangor, v. 10, n. 3, p. 269-282, 2016.

LAI, G.; TANNER, J.; STEVENS, D. The Importance of Mathematics Competency in Statistical Literacy. Advances in Business Research, Texas, v. 2, n. 1, p. 115-124, 2011.

LAVASANI, M. G.; WEISANI, M.; SHARIATI, F. The role of Achievement Goals, Academic Motivation. In: Statistics Anxiety: Testing a causal model. WORLD CONFERENCE ON 
PSYCHOLOGY, COUNSELLING AND GUIDANCE WCPCG, 4., 2013. Istanbul, Proceding of $\mathbf{4}^{\text {th }}$ WCPCG, Istanbul: Elsevier, 2013. p. 933-938.

LEAVY, A. M.; HANNIGAN, A.; FITZMAURICE, O. If You're Doubting Yourself Then, What's the Fun in That? An Exploration of Why Prospective Secondary Mathematics Teachers Perceive Statistics as Difficult.Journal of Statistics Education, New York, v. 21, n. 3, p. 1-26, 2013.

LOVETT, M. "A Collaborative Convergence on Studying Reasoning Processes. A Case Study in Statistics". In: KLAHR, D.; CARVER, S. (Ed.).Cognition and Instruction Twenty-Five Years of. Mahwah: NJ Lawrence Erlbaum, 2001. p. 347-384.

MANDAP, C. M. Examining gender differences in statistics anxiety among college students. International Journal of Education and Research, Dhaka, v. 4, n. 6, p. 357-366, 2016.

MOORE, D. S. New Pedagogy and New Content: The Case of Statistics. International Statistics Review, Voorburg, v. 65, n. 2, p. 123-165, 1997.

NASSER, F. M. Structural model of the effects of cognitive and affective factors on the achievement of Arabic-speaking pre-service teachers in introductory statistics. Journal of Statistics Education, New York, v. 12, n. 1, p. 1-28, 2004.

NCTM. Principles and Standards for School Mathematics. Reston, VA, USA: National Council of Teachers of Mathematics, 2005

ONWUEGBUZIE, A.; WILSON, V. 2003. Statistics anxiety: Nature, etiology antecedents, effects, and treatments - a comprehensive review of the literature. Teaching in Higher Education, Newcaste, v. 8 , p. $195-209,2003$.

ONWUEGBUZIE, A.J.; DAROS, D.; RYAN, J. The components of statistics anxiety: A phenomenological study. Focus on Learning Problems in Mathematics, Chicago, v. 19, n. 4, p. 1135,1997

ROSIDAH. Analysis of Statistical Reasoning Process of Senior High School Students on the Size of Central Tendency (The Case Study For Student's Low Math Ability). In: INTERNATIONAL CONFERENCE ON RESEARCH, IMPLEMENTATION AND EDUCATION OF MATHEMATICS AND SCIENCE. 3., 2016, Yogyakarta. Proceding of $3^{\text {rd }}$ ICRIEMS Yogyakarta: UNY, 2016. p. 225232.

RUMSEY, D. Statistical Literacy as a Goal for Introductory Statistics Courses. Journal of Statistics Education, New York, v. 10, n. 3, p. 1-12, 2002.

SÁNCHEZ, E.; SILVA, C.; CAUTINHO, C. “Teachers' Understanding of Variation”. In: BATANERO, C.; BURRILL, G.; READING, C. (Ed.). Teaching Statistics in School MathematicsChallenges for Teaching and Teacher Education: A Joint ICMI/IASE. New York: Springer, 2011. p. 211-221.

SLAVIN, R., E. Educational Psychology: theory and Practice. 8. ed. Boston: Pearson, 2006.

WATSON, J.; CALLINGHAM, R. Statistical Literacy: A Complex Hierarchical Construct. Statistics Education Research Journal, Auckland, v. 2, n. 2, p. 3-46, 2003.

TEMPELAAR, D. T.; VAN DER LOEFF, S.; GIJSELAERS, W.H. A structural equation model analyzing the relationship of students' attitudes toward statistics, prior reasoning abilities and course performance. Statistics Education Research Journal, Auckland, v. 6, n. 2, p. 78-102, 2007. 
TREMBLAY, P. F.; GARDNER, R. C.; HEIPEL, G. A model of the relationships among measures of affect, aptitude, and performance in introductory statistics. Canadian Journal of Behavioral Science, Washington, v. 32, p. 40-48, 2000.

TÜREGÜN, M. A Four-Pillar Design To Improve The Quality Of Statistical Reasoning And Thinking In Higher Education. TOJQIH - The Online Journal of Quality in Higher Education, Adapazari, v. 1, n. 1, p. 1-8, Jan. 2014.

WILLIAMS, A. S. Statistics Anxiety and Instructor Immediacy. Journal of Statistics Education,New York, v. 18, n. 2, p. 1-18, 2010.

ZEIDNER, M. Statistics and mathematics anxiety in social science students: Some interesting parallels. British Journal of Educational Psychology, Durham, v. 61, p. 319-328, 1991.

ZURAIDA, et al. Cognitive factors influencing statistical performance of diploma science students: A structural equation model approach. In: ICSSBE, 2012, Langkawi. Proceeding of ICSSBE, Langkawi: IEEE, 2012. p. 562-566.

Submetido em 28 de Dezembro de 2017. Aprovado em 12 de Dezembro de 2018. 